[This document contains the author's accepted manuscript. For the publisher's version, see the link in the header of this document.]

\title{
Between Commitment and Pragmatism: Assessing International Influence on Human Rights Practices in Georgia
}

\author{
Mariya Y. Omelicheva
}

\section{Paper citation:}

Omelicheva, Mariya Y. Between Commitment and Pragmatism: Assessing International

Influence on Human Rights Practices in Georgia, Journal of Human Rights, 9(4): 445-466, 2010

\begin{abstract}
:
What explains the discrepancy between the avowed commitment of the Georgian government to human rights and praxis of human rights in the post-Rose Revolution republic? This article engages with this question and attributes persistent breaches of civil, political, and personal integrity rights in Georgia not only to its domestic circumstances, but also to the international impact. The study develops a reference group theory, a type of social theory that stresses the influence of social groups of states on policies and behavior of their members. Reference groups endorse goals, values, and standards of behavior for their members and serve as the "frames of reference" that enable other states to assess the effectiveness and legitimacy of their actions. The findings of this study indicate that Georgia's reference groups, particularly the United States, contributed to its backsliding on human rights by (1) supporting the Georgian government in its goal of rebuilding the state prior to democratizing it and strengthening respect for human rights; (2) redirecting financial and other assistance from democracy promotion to state-building projects; and (3) providing the Georgian government with flattering, yet, misleading feedback concerning the republic's accomplishments in the area of human rights.
\end{abstract}




\title{
Between Commitment and Pragmatism: Assessing International Influence on Human Rights Practices in Georgia
}

Mariya Y. Omelicheva

Assistant Professor

Department of Political Science

University of Kansas

1541 Lilac Lane, 408 Blake Hall

Lawrence, KS 66044

Tel: (785) 864-9002

Fax: (785) 864-5700

omeliche@ku.edu

http://www2.ku.edu/ kups/

\begin{abstract}
What explains the discrepancy between the avowed commitment of the Georgian government to human rights and praxis of human rights in the post-Rose Revolution republic? This article engages with this question and attributes persistent breaches of civil, political, and personal integrity rights in Georgia not only to its domestic circumstances, but also to the international impact. The study develops a reference group theory, a type of social theory that stresses the influence of social groups of states on policies and behavior of their members. Reference groups endorse goals, values, and standards of behavior for their members and serve as the "frames of reference" that enable other states to assess the effectiveness and legitimacy of their actions. The findings of this study indicate that Georgia's reference groups, particularly the United States, contributed to its backsliding on human rights by (1) supporting the Georgian government in its goal of rebuilding the state prior to democratizing it and strengthening respect for human rights; (2) redirecting financial and other assistance from democracy promotion to state-building projects; and (3) providing the Georgian government with flattering, yet, misleading feedback concerning the republic's accomplishments in the area of human rights.
\end{abstract}


Omelicheva, Mariya Y. Between Commitment and Pragmatism: Assessing International Influence on Human Rights Practices in Georgia, Journal of Human Rights, 9(4): 445-466, 2010. Publisher's Official Version:

<http://dx.doi.org/10.1080/14754835.2010.522925>. Open Access Version: <http://kuscholarworks.ku.edu/dspace/>.

Appeared in Journal of Human Rights, 9(4), 2010:445-466.

\section{Between Commitment and Pragmatism: Assessing International Influence on Human Rights Practices in Georgia}

\section{Introduction}

The Rose Revolution of 2003 marked a turning point in Georgia's modern history placing the country on the path of democratic development and changing its policy orientation toward greater respect for human rights and the rule of law. The government of president Saakashvili avowed commitment to individual freedoms and focused intensely on curbing crime and corruption, developing Georgia's economy, and raising the living standards of the population. Today, however, the future of Georgia's democracy remains uncertain. Upon assuming his presidential post, Mikheil Saakashvili moved quickly to consolidate state power in the executive branch by pushing through the parliament significant constitutional changes. Amendments to the Georgian constitution emasculated the state legislature and took away independence from its judicial branch. In the years following the Rose Revolution, the Saakashvili administration began displaying worrisome signs of the growing intolerance of political opposition. It has been accused of recurrent attacks on politically active non-state organizations critical of the governmental reforms, intimidation of business interests, and limitations on media freedoms. In light of these problems with civil and political rights, Freedom House, an independent advocacy group known as the "watchdog" for freedom around the world, removed Georgia from its list of electoral democracies in 2008. The post-Rose Revolution reforms neither reinforced other fundamental human rights nor expanded the people's individual freedoms.

To explain the persistent discrepancy between Georgia's human rights declarations and praxis, this study develops a reference group theory, a type of social theory that stresses the impact of social groups of states on other countries' behavior. A reference group is a state or a group of states that endorses standards of behavior for their members and serves as the "frame of reference" that enables other states to assess the effectiveness and acceptability of their actions. Contrary to the existing explanations of human rights violations that tend to emphasize the impact of domestic context this study underscores the influence of international setting on the situation with human rights in Georgia. It is my contention that Georgia's social environment, i.e., the country's reference groups, particularly, the United States, has contributed to its current predicament in the areas of human rights and democratization by (1) endorsing the Saakashvili government's order of priorities, in which state-building measures became a centerpiece of reforms, whereas democracy and human freedoms were relegated to the secondary importance; (2) redirecting its generous support from democracy promotion to state-building projects; and (3) providing the Georgian government with exaggerated assessment of its progress in the area of human rights and reinforcing a misguided narrative portraying the republic as a thriving democracy and a beacon of liberty.

Shevardnadze's administration passed down a burdensome legacy to the Rose Revolution's architects. In Saakashvili's own words, "everything was in ruins" (Saakahsvili 2006). "Corruption, lawlessness and injustice reigned supreme," and there was no budget or operational army in Georgia (Saakashvili 2005). The governments of the United States and other European nations entrusted the new regime with leading the country's difficult transformation, and Saakashvili and his cabinet had considerable discretion in prioritizing some political projects over others. While the leadership of the country has been genuinely committed to human rights, it, however, placed a higher premium on the rebuilding of the state. Most of the Western states, 
including the United States, not only supported Georgia's decision to prioritize state-building at the expense of human rights and democracy, but also reoriented their support from various democracy promotion programs to other initiatives aimed at bolstering the state. The US administration was very reluctant to criticize the post-Rose Revolution regime or even publically discuss the obvious problems with human rights in the country. The US relationship with Georgia became personalized, and the American assistance to human rights and democracy in the republic degenerated in President Bush's support for Saakashvili and his cabinet.

The case-study that follows examines a wealth of data to test propositions about the impact of international environment on human rights practices in Georgia. I systematically content analyzed reports published by governmental and non-governmental, international and Georgia-based organizations including, but not limited to: annual reports on human rights published by the US Department of State, PACE reports, publications of Human Rights Watch (HRW) and Amnesty international (AI), releases of Georgia-based Human Rights Center and the Georgian Ombudsman. I also examined speeches and statements of Georgia's president and other public officials, as well as news articles in Georgian press downloaded using the search engine of the East View Universal Databases.

The first section of the study presents the reference group approach. Next, I apply its premises for establishing Georgia's reference groups. The third section contains an overview of Georgia's human rights practices since the country's independence following by the analysis of the Georgian reference groups' influence on the republic's human rights situation. A summary of findings and discussion of the outcomes of Georgia's reforms concludes the research.

\section{Theory of Reference Groups}

Researchers across multiple disciplines have worked painstakingly for decades to identify the causes of state repression and conditions conducive to respect for human rights. An important outcome of these investigations has been the discovery of a number of factors associated with the governments' abuses of human rights. Three clusters of causes affecting human rights policies are (1) political factors encompassing characteristics of political system and presence of threats to the state and the governing regime; (2) economic explanations focusing on poverty, inequality, economic growth, or globalization; and (3) cultural, historical, ideological, and psychological explanations including human predisposition to obey authoritative orders, historical intercommunal hatred, and colonial or communist legacy among many others. ${ }^{1}$

International relations scholars have rightly pointed out that all of these theories, with the exception of explanations highlighting the impact of international wars and foreign assistance, underscore domestic sources of state repressions. States, however, do not act in isolation. They interact with and evaluate their behavior against activities of other states and international organizations. Comparisons of this kind shape decision-making "menus" of possible approaches to human rights and influence choices of behavioral responses from a number of alternatives. These comparisons and evaluations can be domestic and historical. More often, however, they are contemporary and international. The scholarship of international human rights has identified a range of international actors that can affect the decision-makers" "menus" of human rights policies, and contributed important insights about the mechanisms of their influence on the decision-making processes concerning human rights.

While recognizing the impact of domestic context on the human rights situation in Georgia, this study underscores the role of international setting. Contrary to the existing international explanations of human rights practices, which lack the micro-foundations of international influence or are ambivalent about the factors that make policies of some 
international actors more influential and attractive than others, I propose an integrative theoretical framework combining international and domestic determinants of human rights practices and systematizing different mechanisms of international influence on states' behavior. In this research, I adopt a reference group theory, which articulates how various groups of states with which other states identify or whose resources are perceived as necessary for accomplishing the states' political, economic, and other goals, affect their human rights measures. ${ }^{2}$ With respect to human rights, a reference group is a state or a group of states that guides and orients other states' human rights practices by endorsing and enforcing human rights principles and by providing information about the legitimacy and effectiveness of human rights measures.

Every social group has an implicit or explicit set of beliefs, values, and behaviors that are considered appropriate for the group's members. A state can follow expectations of its social group in the area of human rights for instrumental reasons, i.e., for securing material benefits, such as military and economic assistance, or avoiding sanctions mediated by others. A group of states that is believed to wield significant power, which can be used for providing tangible rewards or imposing material losses on the state, is known as its utilitarian reference group. Alternatively, a government's conformance to other states' policies may be driven by valueexpressive motives, which refer to a state's need to enhance its positive image. According to social psychologists, individuals have a natural need for high self-esteem, and this need translates into the realm of states (Curley 2009: 651). To heighten its image and self-esteem, a state may seek identification with other states by aligning its values with those of others and by conforming to other states' expectations (Herek 1986: 106). The letter group of states is known as the normative reference group (Hyman 1968; Kelley 1952). By embracing the normative reference groups' values, a state gains a symbolic sense of acceptance by the group. This outcome can heighten the state's self-image and lead to an enduring sense of self-worth (Blanton and Christie 2003: 123).

Contrary to the influence of a normative reference group, which typically results in internalization of the group's norms through socialization, the influence of the utilitarian group is more transient, costly, and superficial (the adoption signified mere behavioral adaptation, which is externally imposed by manipulation of punishments and rewords). If a state accepts the policies and perspectives of its normative reference group, it is very unlikely that the state will change its position even when the reference group exerts no pressure to induce compliance with its policy preferences or recommendations. Compliance with the utilitarian group's influence requires constant attempts at influence, and surveillance by the group.

Coupled with prescriptions of the utilitarian and normative reference groups to "do this," or "abstain from doing that," there is also a need to know how to accomplish a desirable goal, or how well a state performs on a certain task. A group of states that provides other governments with a frame of reference for making appraisals of their performance is known as a comparison reference group. Comparison groups' information is used for facilitating states judgments about legitimacy and adequacy of their actions. Comparison reference groups can also serve as the role-models that inform other states on how to excel in the selected course of action.

Reference groups' norms, values, and knowledge can be communicated through a variety of written, verbal, and behavioral channels. Norms and perspectives of reference groups are often contained in the groups' written records, such as treaties, conventions, or instructions to prospective members on how to bring their practices and legislation in accordance with the reference group's expectations. The rhetoric of the group's members - their public announcements and speeches - typically contains references to values of the reference group. To 
make the reference group's preferences known to others, its members can also issue direct orders and requests, apply persuasion tactics, or engage in negotiations with other states. The observable actions of the reference group's members also express their adherence to certain principles and norms.

Feedback is the most important channel of communication between reference groups and their members. Not only does it provide another avenue for inferring the groups' perspectives, but also supplies information that features strongly in states' self-appraisals. As positive feedback, the group can bestow recognition or membership on a state. Suspension of the state's membership, isolation, expulsion, and exclusion from the group's activities are all examples of the group's disapproval of the state's actions. Feedback can also be conveyed through verbal and written communication, such as, for example, praising the state leadership for human rights advances, or criticizing authorities for violations of human rights.

A state, typically, belongs to several reference groups. The prominence of a reference group, its ability to capture the attention of political elites and induce the state's behavioral compliance, is known as the salience of the group. The salience of a utilitarian reference group depends on the intensity of a state's instrumental goals and the ability of the utilitarian group to satisfy them. A factor that determines the salience of the normative reference group is the "social psychological proximity" developed on the basis of perceived historical, institutional, and value similarities (Rose 1993: 105; Weil 1993: 198). Among other factors that strengthen the appeal of normative reference groups are their status, tangible and intangible benefits of being a part of the groups (Agyeman-Duah and Olatunde 1991: 299), geographical proximity (Mooney 2001), and acceptance by other members of the group. Perceived similarity as well as the perceived expertise of a reference group in a specified issue area will influence its salience as a role model.

The reference group is a perception-based social category, or a product of the "hot" and "cold" cognition of the leadership of individual states. The state decision-makers conceive of their states as belonging to a certain social category of, for example, European democracy. They utilize foreign lessons and ponder over the merits of incorporating other states' suggestions into domestic reforms. They are the recipient ends of international pressure. Therefore, the study into the impact of reference groups has to be performed as the social psychological level of analysis examining perceptions and views of individuals vested with the key tasks of state policy-making. These motivations and views can be inferred from a variety of perceptual and behavioral data such as speech acts, written communications, behavioral reactions, and artifacts of interactions of political elite. For this study, I examined the Georgian politicians' speeches and statements accompanying their political decisions in order to demonstrate conscious policy-following for instrumental, value-expressive, or informational reasons.

\section{Georgia's Reference Groups}

According to the reference group approach, governments adopt policies and perspectives of other states for utilitarian, value-expressive, and informational reasons. The more pressing a government's political, economic, security and other needs are, and the better a social group can serve those needs, the stronger its influence on this government will be. According to the Georgian government, Russia, the US, and, to a lesser extent, the EU and individual European nations have exercised considerable influence on Georgia since the republic's independence. ${ }^{3}$ The section that follows briefly explores the roles that these states have played in Georgia's politics and foreign policy and examines the underlying reasons for their influence on the Georgian authorities. 
After independence, Georgia encountered a gamut of political, security, social, and economic issues. The separatist conflicts in South Ossetia and Abkhazia escalated into devastating civil wars that threatened to tear the republic into several sections. The ousted first president of Georgia, Zviad Gamsakhurdia, established a "government in exile" in 1993 and led his supporters against the poorly equipped and demoralized Georgian army (Curtis 1995). The rest of the country submerged in the growing poverty, lawlessness, and corruption. Compelled to resolve political and economic problems in his state, Eduard Shevardnadze, who assumed the leadership post in the republic in 1992, sent an urgent appeal for an outside military and economic assistance. In the summer of 1992, Russia mediated a cease-fire with South Ossetia and Russian troops were sent to Abkhazia for quelling Gamsakhurdia's uprising. The brutal fighting was brought to an end, but the separatist conflicts have not been resolved. The proindependence aspirations of South Ossetia and Abkhazia have since been perceived as the threats to Georgia's national security, territorial integrity, and independence.

Bitter political conflicts and a deep economic crisis necessitated re-activation of Georgia's relations with Moscow and the Moscow-led Commonwealth of Independent States (CIS). Shevardnadze's policy of rapprochement with Russia was viewed as necessary for remedying the country's political and economic situation (Vasiljeva 1997). Russia provided the republic with the much needed political, military, and economic support, while Georgia acceded to Russia's demands of joining the CIS and signed an agreement on military cooperation with the Kremlin. After the breakup of the USSR, Georgia's political structures retained the Soviet-era makeup because the majority of the Soviet-era elite held on to their posts after Georgia's independence. Many of those public servants reminisced about the Soviet epoch (Vasiljeva 1997). Consequently, the first generation of Georgia's political leaders was particularly susceptive to political practices that outlived the communist era, despite their open rejection of the values of communism and socialism.

All Georgian governments have supported Georgia's pro-Western orientation. The republic's integration in the EU and NATO has been viewed as a viable solution to its economic and security predicament. In the early 1990s, however, the desired level of Western support was not forthcoming. The unpredictable foreign policy and extreme nationalism of Zviad Gamsakhurdia almost completely isolated the country. The US government decided not to intervene in Georgia-Russia relations, and suggested that the Georgian government, itself, find ways of building its relations with Russia. Europe, too, was too fearful of political instability on its southern borders to embrace the young republic in its fold. The Western donors developed mistrust of the Georgian authorities who habitually misused foreign funds and embezzled state finances. The level of assistance from the US and Europe increased throughout the 1990s but it lacked compelling incentives and strategic focus for inducing the country's "Westernization." Appeals for democratic reforms had been heard repeatedly during the Shevardnadze reign, but the genuine political and economic reforms dragged out over years. Therefore, both the EU and the US had remained duly skeptical about the authenticity of Georgia's commitments to democracy and human rights that represented, at most, a desire and not a realist portrait of the situation in the republic.

The breakthrough in Georgia's relations with the West occurred after the 9/11. The terrorist attacks galvanized the US foreign policy that has since been balancing the goal of combating terrorism with the vigorous pursuit of democratization. The Bush cabinet significantly increased strategic assistance to Georgia in 2002 in response to Russia's threats of unilateral preemptive strikes at the republic's tumultuous Pankisi region, an alleged campground of the 
Chechen terrorists. The Bush government also provided strong political backing to the new Georgian leadership that replaced the disgraced Shevardnadze's administration in 2003. By that time, Moscow's utilitarian influence over Georgia dwindled since Russia's own deplorable security and economic situation depleted its sources of influence. Georgia developed a strong perception of Russia as a contributor to conflicts in South Ossetia and Abkhazia, a direct security threat, and a major impediment to the realization of Georgia's national goals. The Kremlin's actions have been described as "permanent efforts aimed at annexation" of the Georgian territories (Parliament of Georgia 2005) and an attempt to re-divide the "post-imperial space" (Saakashvili 2006). Moscow's relations with Tbilisi have been interpreted as informational, energy, and trade "wars," while Russia's resentment to Georgia's NATO aspirations have been construed as an attempt to keep Georgia in Russia's orbit of influence. Russia developed into Georgia's negative group whose policies the Georgian government began to resist. The United States, on the other hand, that provided Georgia with important security guarantees, security assistance, and political patronage has become Georgia's primary utilitarian group.

To sustain the American politicians' interest in Georgia and to ensure the constant flow of monetary and other assistance to the republic, the government of president Saakashvili vowed to turn the poverty-stricken country into a prosperous West-leaning state. It launched a series of comprehensive political, security, economic, and judicial reforms and aligned the goals, orientations, and values of the country with those of the US and other European nations. The Georgian Parliament reaffirmed "the strong will of the people of Georgia to build a united, democratic and European state," and to "develop Georgia's defense policy as an integral part of common European and Euro-Atlantic security policy" (Parliament of Georgia 2006). Georgia's reforms have been fashioned as a direct manifestation of Georgia's "Europeaness," while its relations with the US have been portrayed as partnership "based on a common commitment to the universal values inherent in democratic governance" (Government of Georgia 2005: 34). The Georgian government has employed various means of symbolic politics to forge Georgia's "European identity" and created a number of "European narratives" describing historical ties of Georgia with European states (Saakashvili 2004a, Saakashvili 2004b).

The EU has been a stalwart supporter of Georgia's territorial integrity, and backed the Saakashvili government in its row with Moscow. It, nonetheless, has refrained from more direct forms of involvement in South Ossetin and Abkhazian conflicts (Lobjakas 2006). The EU officials have been very cautious about Georgia's chances for eventual membership in the European Union. As the EU foreign policy chief Javier Solana put it, "being closer to the European Union doesn't mean being part of the European Union... we can sign with countries very profound cooperation agreements, but membership is a different story..." (Tamrazian and Aliyev 2006). Due to the Union's reluctance to afford Georgia a place in Europe, the EU's influence over Georgia has been characterized as moderate or weak depending on the area of the EU-Georgia cooperation. The Saakashvili government has come to realize that Georgia's accession to the EU is out of question in the foreseeable future. Georgia's membership in NATO, however, remains a feasible aim. Until the November 2007 crisis, the Georgian government was confident that NATO would offer the country a Membership Action Plan at its Bucharest Summit in April 2008. The violent clampdown on the anti-government protestors tainted Georgia's reputation, and the country did not receive the desired candidacy status in Bucharest. Short of the membership in the Northern Alliance, Georgia has to rely on the protection and backing of the US administration. The United States, which has provided the republic with 
generous financial backing, security assistance, and political patronage, has become Georgia's primary utilitarian, normative, and comparison reference group.

\section{Human Rights in Georgia Since Its Independence}

During ten years of Shevardnadze's rule, Georgia was infamous for the dismally poor record of human rights practices. While the Shevardnadze administration was formally committed to human rights, its practices always departed from the formal commitments. There were frequent violations of civil and political rights manifested in electoral fraud and prosecution and harassment of political and business rivals. The physical abuse of detainees, mistreatment during interrogation, and violations of due process were not unheard of during the Shevardnadze time as were the instances of the direct government's involvement in politically-motivated trials and exercise of pressure on courts. The dissolution of the Soviet Union and its socialist system, extreme economic conditions, and political crisis gravely affected the human rights situation in the republic. The Georgian state was disorganized, fragmented, and weak. The legacy of the Soviet-era law enforcement practices, citizens' suspicion of public institutions, and the shortfall of trust in both public and private life contributed to the deficit of civil engagement, lack of public oversight, and, ultimately, to persistent human rights violations. Furthermore, human rights concerns did not transpire in politics of the Russian Federation, Georgia's primary reference group at the time. Neither were they prioritized in Moscow's relations with the Shevardnadze cabinet. Russia, itself, evinced a despicable human rights situation and served as an unfortunate model for other states to emulate.

Human rights were part of the broader democratization agenda of the US, Europe, and other foreign donors, which implemented a variety of programs aimed at strengthening democratic institutions - parties, parliament, and elections - and encouraging civil society and local governance in Georgia. Despite this generous international support (Georgia, for example, received more than US\$700 million in American direct aid in 1995-2000, and over 420 million euro from the European Union between 1992 and 2004), foreign assistance had a limited, and, at the most, moderate impact on human rights practices in Shevardnadze's Georgia (Tudoroiu 2007: 322). The amount of aid was incommensurable to the problems and challenges faced by the state. The assistance provided by the US and Europe was not strategic and lacked a unifying goal of human rights and democracy promotion. The foreign funds were used to advance some short-term, incremental, and scattered goals, and human rights were often at the margins of the democratization agenda emphasizing electoral processes or professionalization of the Georgian staff. Importantly, the old Georgian leadership lacked genuine commitment to human rights, and its dependence on Russia deprived the Western states of decisive leverage over the Georgian administration.

Western money and various forms of assistance were, nonetheless, instrumental for the growth of Georgia's civil society. Ironically, thanks to the weakness of the Georgian state and frailty of its economy, there was an ample space for the emergence of civil activism, the exercise of free speech, and practice of the freedom of associations (Mitchell 2009c: 26). Despite the instances of intimidation and violence against journalists, there was no institutionalized censorship of the television and press, and investigative journalism flourished in Georgia. A weak state was incapable of closing this space and keeping a lid on the freedoms of speech and assembly. Georgian citizens flocked around the civil society sector, lavishly funded from abroad, which allowed the civil society organizations to pay people decent salaries (Tudoroiu 2007). Foreign support combined with a relatively free informational and associational climate begot a vibrant and diverse civil society in Georgia capable of organizing and mobilizing people 
throughout the country (Mitchell 2009a: 175; Tudoroiu 2007: 322). Georgia would not have seen the Rose Revolution without this citizens' activism.

The Saakashvili government inherited the country that suffered from democratic deficit, deplorable economic situation, and the lack of respect for human rights. Immediately, it announced a program of wide-ranging measures aimed at eliminating endemic corruption, strengthening the state, modernizing economy, and resolving the separatist conflicts.

Saakashvili's government also reiterated its commitment to democratization, adherence to human rights, and a pro-Western foreign policy orientation (Saakashvili 2004a, 2004b). Not only has the Saakashvili team made great advances in the fight against corruption and lawlessness in the state, and improved economic indicators in the country, but it has also taken steps to rectify Georgia's human rights situation. In the aftermath of the Rose Revolution, the new Georgian authorities adopted unprecedented measures aimed at preventing human rights abuses by the police and putting an end to the impunity of those responsible for mistreatment of prisoners and detainees. A Department of Human Rights and Monitoring stuffed by the NGO representatives was set up in the Ministry of Internal Affairs for monitoring police stations and prisons. The government established a new office of the Public Defender (the Georgian Ombudsman) to oversee the criminal justice system. A Human Rights Protection Unit was created in the Office of the Prosecutor General for overseeing investigations of the cases of torture and mistreatment.

In 2005, the Georgian parliament criminalized torture and inhuman and degrading treatment, and a year later Georgia became a party to the Optional Protocol of the UN Convention against Torture. The Constitution of Georgia was amended with a provision disallowing torture under any circumstances. The parliament passed amendments to the criminal procedure code and other laws with the aim of strengthening safeguards against torture (AI 2007). The Georgian law-enforcement agencies developed individual codes of ethics for judges, prison employees, prosecutors, and police. These documents establish human rights standards in the courtrooms, detention facilities, and with regard to the use of force, and define disciplinary actions for violations of the codes (U.S. Department of State. Bureau of Democracy, Human Rights, and Labor 2007). The new government also made great strides in the area of political freedoms, and Georgia's 2004 parliamentary elections were extolled as the most democratic since its independence.

Despite these and other measures adopted by the Saakashvili government, many organizations, including AI, HRW, the World Organization against Torture, the International Federation for Human Rights (IFHR) and others have called attention to lagging human rights problems in Georgia (AI 2007; HRW 2006; IFHR 2006). The UN Committee against Torture summarized concerns of the human rights groups in its annual report in the following way, "impunity and intimidation still persist [in Georgia], in particular in relation to the use of excessive force, including torture and other forms of ill-treatment by law-enforcement officials, especially prior to and during arrest, during prison riots and in the fight against organized crime" (Committee against Torture 2006). This conclusion echoes the findings of annual human rights reports published by the US Department of State and concerns about Georgia raised at the Parliamentary Assembly of the Council of Europe (U.S. Department of State. Bureau of Democracy, Human Rights, and Labor 2007, 2008; see also AI 2009).

Georgian police continues fabricating and planting evidence, while the judiciary lacks experience and independence. According to a public opinion survey conducted in 2008, only $22.6 \%$ of respondents believed that everyone in Georgia was equal before the law, and less than 25\% felt secure against unjust state actions (Sumbadze 2009: 185). The allegations of political 
imprisonment persist, and human rights groups have published accounts of politically motivated killings (Human Rights Information and Documentation Center (HRIDC) 2006b; HRW 2009b). The lack of concern for human rights violations can be evidenced at all levels of state administration. President Saakashvili, himself, has encouraged the law-enforcement officials to depart from their human rights obligations. In January 2004, for example, Saakashvili declared on the main television channel in Georgia,

I... have advised my colleague Zurab Adeishvili, Minister of Justice - I want criminals both inside and outside of prisons to listen to this very carefully - to use force when dealing with any attempt to stage prison riots, and to open fire, shoot to kill and destroy any criminal who attempts to cause turmoil. We will not spare bullets against these people (HRIDC 2004: 5).

A month later, Saakashvili explained to the newly appointed judges,

Policemen have instructions to fire directly because the life of one policeman is more valued than the lives of entire world of criminals and their accomplices, to me and to the public. Therefore, here we made precedents to use arms and we intend to continue this way, same as practiced in USA, Europe, Israel and all other developed countries (HRIDC 2006a: 28).

Georgia's Minister of Interior, V. Merabishvili also encouraged policemen to use arms during operations endangering their life. Georgia's public officials habitually refer to detainees as criminals and declare persons guilty before a court determines that their actions constitute a crime. When the Council of Europe issued an alarming report concerning the status of human rights in Georgia and the Monitoring Group of the Parliamentary Assembly put forth its recommendations, Saakashvili dismissed those as "provincial and funny fuss". The President stated that recommendations are "good but we are an independent county and our people will decide how to rule the country" (HRIDC 2006b: 10-11).

The new Georgian government has become increasingly intolerant of any form of dissent, and the freedom of speech and assembly received some setback (U.S. Department of State. Bureau of Democracy, Human Rights, and Labor 2008). "Reporters Without Frontiers" registered significant drop in the index of media freedom in Georgia since the Rose Revolution (HRIDC 2006b). The fragility of the Georgian government's commitment to human rights was exposed on 7 November 2007, when it ordered the Georgian troops to disperse a series of demonstrations in Georgia's capital. Convened by the opposition parties, thousands of protesters demanded free and fair elections and criticized the government for seizing all power in the country and neglecting human rights. On the fifth day of rallies, police and security forces applied disproportionate force to disband the protesters reportedly injuring hundreds of them (HRW 2007: 2). President Saakashvili declared a state of emergency, which entailed the suspension of broadcasting by three television stations. One of the broadcasting organizations, Imedi, was raided by the special force units, which destroyed much of the station's equipment and threatened its staff (HRW 2007: 1). Many political and civil rights continued dwindling in the aftermath of the November demonstrations. Scores of the rallies' participants were arrested or harassed, and the government continued restricting freedoms of speech and assembly (U.S. Department of State. Bureau of Democracy, Human Rights, and Labor 2008).

The snap presidential elections called for by Saakashvili in the aftermath of the November crackdown and parliamentary elections of 2008 were conducted in a politically charged atmosphere and marred by intimation and pressure against opposition activists. Both elections were criticized for the use of administrative resources by the incumbent president and 
his pro-Presidential National Movement party and other irregularities. In August 2008, Georgia became involved in a controversial military operation in South Ossetia and war with Russia, which have further deepened the rift in the Georgian society and fractured Saakashvili's team. Several erstwhile supporters of the president, former parliament speaker Nino Burjanadze and Georgia's ambassador to the UN Irakli Alasania, left Saakahsvili's administration and formed an opposition block. Political opponents of the president launched a new cycle of demonstrations in April 2009 demanding his resignation, changes in electoral legislation, depolitization of lawenforcement structures, and other reforms. Initially, the government exercised significant restraint in responding to protests. Eventually, however, it resorted to attacks on opposition demonstrators (AI 2009; HRW 2009a). Georgia's Public Defender charged the government with stamping on human rights under the pretext of restoring order and strengthening the state, and blamed it for leading the country toward a one-party dictatorship.

\section{Assessing the Influence of Georgia's Reference Groups on the Republic's Human Rights Practices}

A manifest discrepancy between the avowed commitment to human rights and adherence to those pledges in practices in the post-Rose Revolution Georgia is the main puzzle of this study. I attributed the status of human rights in Georgia to not only its domestic circumstances but also international influence. It is my contention that Georgia's reference groups contributed to its retreat in the area of human rights. The United States (and, to a lesser extent, the EU), as Georgia's primary normative reference group de-prioritized human rights in its expectations advanced toward the Georgian government and supported Saakashvili's drive toward statebuilding at the expense of democracy. As utilitarian reference groups, both the US and the EU failed to condition their support to Georgia by unwavering commitment to human rights. The US government began channeling its foreign assistance away from the civil society projects that received US backing during the rule of Shevardnadze. Finally, as the comparison reference groups, both the US and the EU provided the Georgian government with inflated assessments of its progress in democratization that the Saakashvili cabinet used in gauging its success and accomplishments in the area of human rights. Below I elaborate on these points.

The new Georgian government inherited a host of serious problems from Shevardnadze's time. Although, the Saakashvili team has shown determination in grappling with every facet of Georgia's predicament, it had to prioritize between several competing aims. Since the Georgian state was in ruins and needed to be revitalized for leading the country through sweeping reforms, state-building became a priority for the Saakashvili administration, while democratization and human rights receded to the secondary importance until the task of rebuilding of the Georgian state was done (Mitchell 2009a: 178; 2009c: 99). Most Western governments, particularly, the Bush administration, tacitly or openly supported this order of priorities (Papava 2006: 662). Georgia's quest to become a part of the "West" translated into the goal of building the Western state that meant first and foremost a strong and efficient nation-state, and, then, a liberal democracy. To reiterate, there has been genuine commitment to democratization in Georgia, and this goal has been repeatedly stressed by the Georgian elite, particularly in their English speeches delivered to the Western audiences. However, as I demonstrate below, the goal of state-building took precedence over the one of building a democracy in Georgia.

Saakashvili's team, exploiting its post-revolutionary mandate, began rebuilding the state at a frantic pace. The first step was the consolidation of power in the office of the president that would have allowed the government to push through other reforms and urgent measures. Immediately after taking his office, Saakashvili initiated significant constitutional changes that 
were rushed through the parliament in one week allowing for neither substantial discussion nor public input or feedback from international experts. Amendments to Georgia's constitution strengthened the post of the president at the expense of the legislative and judicial branches. As a result, Saakashvili acquired more formal power than Eduard Shevardnadze ever had (Mitchell 2009c: 80). The executive authority has been bolstered by a compliant legislature where the propresidential party retains the majority of seats, while political opposition remains weak and divided. The judiciary was degraded and judges have been compelled to implement decisions of the public prosecutors out of the fear of losing their positions (Papava 2006: 662). Neither the US nor Europe expressed any reservation about the direction of reforms, which emasculated the system of checks and balances leading to the concentration of power in the hands of a highly charismatic and outspoken leader. The latter surrounded himself with a team of like-minded politicians with personal ties to the president (Chivers and Chanker 2009; Tatum 2009: 162). Under these circumstances, the abuse of power by the public authorities has become a recurrent and dangerous trend, and a major issue dividing political circles and angering the population.

The consolidation of power allowed the Saakashvili cabinet to launch a high-profile drive against corruption that led to the increase of revenues in the republic's budget, growth of pensions, and reduction of state arrears. Borrowing from a wide arsenal of methods for coping with organized crime in the US, Italy, and other Western states, Saakashvili's team enacted a plea bargaining system according to which individuals suspected in graft could return the stolen property and money and walk free of the criminal prosecution (Kukhianidze 2009: 215-6). On one hand, the confiscated assets filled the government's coffers with the much needed cash that was used for supporting a wide range of socio-economic programs. On the other hand, the establishment of an extra-budgetary system of "law-enforcement development accounts" led to the emergence of a new form of corruption in the highest echelons of power, and a perception of immunity of criminal bosses who could "buy out" their freedom (Papava 2006: 663). In its revolutionary zeal to root out corruption and organized crime, the Georgian police, which continued to lack professionalism for investigating criminal cases competently and in accordance with high ethical standards, habitually violated the criminal code and resorted to Soviet-era practices of planting criminal evidence, torturing detainees, and applying disproportionate force (Kukhianidze 2009: 215-6). Despite these excesses in criminal investigation, the Western nations acclaimed and supported the Georgian war against graft.

The introduction of a new tax code, privatization campaign, and a series of measures aimed at improving the country's investment and business climate have been widely commended by the West. These sweeping reforms, however, have targeted broader socio-economic sectors, such as the areas of finance, energy, and military, whereas the local issues and problems have received little heed (Tatum 2009). In 2005, for example, more than a half of the Georgian population lived below the poverty line. This, however, did not prevent the Georgian administration from spending one-fifth of its budget on defense. In 2007, the government spent 27\% of its expenditures on the military sector (International Crisis Group 2007: 11-12). In 2008, the military budget amounted to about $10 \%$ of Georgia's GDP, a figure that five times more than NATO's guidelines of 2\% (Nichol 2008b). The overhaul of the Georgian army has been the most impressive accomplishment of the Saakashvili administration. Strenuous efforts at reforming the Georgian military have been consistent with the drive for rebuilding the state, which national power is typically associated with the strong military.

The goals of the Georgian government have been consistent with the US priorities in the republic. The US administration has repeatedly stated that security was the foundation of all 
other dimensions of relations between Georgia and the US (U.S. Embassy in Georgia 2009). The US-Georgia Charter on Strategic Partnership signed at the end of the second Bush's term reiterates that increasing Georgia's defense capabilities and modernizing the Georgian military are the main objectives of the US-Georgia partnership (U.S. Embassy in Georgia 2009). Other areas of cooperation discussed in the charter are economic trade and energy cooperation, advancing democracy and the rule of law, and strengthening the cultural times between the two states. The issues of trade, democracy, and culture have been marginalized in both the rhetoric and practice of the US administration. Georgia has become a "premier partner" of the US in its global war on terrorism because of its geopolitical location and because the republic became one of the biggest per-capita providers of servicepersons for military operation in Iraq (Congressional Presentation for Foreign Operations for FY2007 as cited in Nichol 2008a: 29; Nichol 2005). Georgia has also played an important role in furthering American energy interests, securing the flow of energy resources from the Caspian sea to the West, and diversifying energy sources for the US and Europe. Therefore, for the US, partnership with Georgia has served security goals, including meeting the challenge of energy security and promoting peace and stability in the region (The White House 2009).

The primacy of state-building over all other goals of the Rose Revolution, including human rights and democracy, can be further evidenced in Saakashvili's speeches and public statements. I systematically analyzed the Georgian president's addresses to the people of Georgia, annual reports to the parliament, and numerous speeches and interviews delivered to the Western audiences. In his first annual report to the Georgian parliament, broadcasted in February 2005, Mikheil Saakashvili referred to Shevardnadze's Georgia as "a failed state - disintegrated, demoralized and humiliated," and a country "that had lost all attributes of statehood." From the very beginning of the report, Saakashvili stressed the goal of "regaining the motherland that had been lost and taken away." Notably, there were very few invocations of democracy or references to human rights in the president's assessment of achievements during the first year of his administration (Saakashvili 2005). A year later, when Saakashvili delivered his second address to the Georgian parliament, he, again, restated his impression about Shevardnadze's Georgia as a "finished" state. The primary goal for the new Georgian administration, as articulated by the president, was to build a "strong and decent Georgia" (Saakashvili 2006). These themes of statebuilding have reoccurred in the statements and reports delivered over the following years by Saakashvili and his teammates. Other symbolic gestures of the president also suggest that Saakashvili is a state-builder first, and democrat, next. Upon assuming his post, Saakashvili, for example, took an oath on the tomb of King David the Builder, perceived by Georgians as the defender and unifier of the Georgian state. Domestically, Saakashvili has occasionally compared himself to King David as well as to Kemal Ataturk, a Turkish revolutionary statesman known for his efforts at building the Turkish state (Mitchell 2009a: 178-9).

Saakashvili's state-building program with its focus on anti-corruption measures, military reform, and strengthening the executive vertical of power, undermined some of its democratization efforts and shifted attention away from human rights. These measures, at times accompanied by a belligerent and divisive rhetoric of the Saakashvili administration, also increased the social, economic, and political vulnerabilities of Georgia's ethnic and cultural minorities, contributing to their resentment and alienation from the state, and inciting aggressive state action (George 2009: 135). In its zeal to quickly transform the country, the government has also lost touch with the needs and concerns of the ordinary citizens and allowed considerations of expediency to trump some democratic principles and human rights (HRIDC 2008: 9). 
Georgia's reference groups contributed to creating and maintaining a false dichotomy between state-building and democratization by encouraging the goal of state-building and supporting the priorities established by the Georgian government. They also reoriented their financial, technical, and other kinds of assistance from democratic projects to state-building initiatives. It is no exaggeration to say that without the generous assistance from the West, Georgia's reforms would have been endangered by severe deficit of recourses. The new Georgian administration has been dependent on Western largesse, and Western donors could exercise substantial leverage over the course and direction of the country's transformation.

The US administration has reduced its support to Georgia's civil society and mass media organizations, which were regarded as the vehicles of democracy promotion under the Shevardnadze regime. According to Western donors, the Saakashvili government, itself, exemplified the potent force for democratization (Mitchell 2009c: 6). International Foundation for Electoral Systems (IFES), for example, one of the leading electoral assistance organizations, which had been engaged in a series of projects aimed at strengthening democratic process in Georgia since 1998, shut down its activities in the republic in 2004 due to financial hurdles. This happened at a time when Georgia was expected to hold several national elections within a short period of time. IFES resumed some of its activities in 2008. Two other US-based nongovernmental organizations, the National Democratic Institute and the International Republic Institute, had to scale down their operations in Georgia due to reduction in funds.

The American monetary assistance and expert advice have been used for reforming judiciary, law enforcement, and military agencies and training their personnel. The US aid went toward legislative reforms, particularly in the areas of foreign investment, energy, budget, and taxation. It accelerated Georgia's transition to a more transparent market economy and improved business environment conducive to foreign investments and domestic entrepreneurship. In other words, the US assistance enabled the Georgian government to rebuild the Georgian state. The Bush administration continued to provide money for promoting democracy and human rights in Georgia. However, even in the USAID democracy promotion initiatives the accents shifted toward strengthening the national governance institutions through, for example, assistance to the office of the Georgian president, government, and individual ministries in streamlining their office management, information flow, and inter-ministerial coordination, or training the staff of the governing institutions in communications and outreach. Projects aimed at strengthening civil society, human rights protection, and equal access to justice received significantly less funding than programs of national governance (Mitchell 2009c: 129; USAID 2006, 2009).

Table 1 summarizes US financial support to pre- and post-Rose Revolution Georgia. The American strategic assistance to the republic, i.e., funds for reforming the Georgian military and bolstering the government's capabilities at fighting terrorism, have increased significantly. In 2002, the US government announced about a 20-month, \$64 million plan, for Georgia's Trainand-Equip Program, and additional $\$ 60$ million were allocated for a new Sustainability and Stability Operations Program in 2004. American officers trained the majority of Georgia's armed forces, as well as a number of security and border officers and police (Nichol 2005). Also, in 2004, Washington declared Georgia eligible for the Millennium Challenge program, and a year later the government of Georgia signed a five-year \$295.3 million compact within its framework (Millennium Challenge Corporation 2005). Thus, Georgia became the largest recipient of the American per capita assistance in the post-Soviet territory. After the August 2008 conflict between Russia and Georgia, the US government pledged \$1 billion aid package for Georgia to 
assist the country's recovery after the devastating war. This amount is 30 times greater than past annual American aid to the country (HRW 2009c).

Table 1. U.S. Assistance to Georgia (1992-2007)

\begin{tabular}{|r|l|l|l|l|l|l|l|l|}
\hline & $\mathbf{2 0 0 7}$ & $\mathbf{2 0 0 6}$ & $\mathbf{2 0 0 5}$ & $\mathbf{2 0 0 4}$ & $\mathbf{2 0 0 3}$ & $\mathbf{2 0 0 2}$ & $\mathbf{2 0 0 1}$ & $\begin{array}{l}\mathbf{1 9 9 2} \\
\mathbf{0 0}\end{array}$ \\
\hline $\begin{array}{r}\text { Total FAS } \\
\text { Fund } \\
\text { Expended* } \\
\begin{array}{r}\text { Total for } \\
\text { USAID } \\
\text { programs }\end{array}\end{array}$ & 44.41 & 50.54 & 58.89 & 57.16 & 55.66 & 67.22 & 59.26 & 209.53 \\
\hline $\begin{array}{r}\text { Total Non- } \\
\text { FSA Fund } \\
\text { Expended ** }\end{array}$ & 58.40 & 91.63 & 45.47 & 56.34 & 43.45 & 50.94 & 28.64 & 401.73 \\
\hline $\begin{array}{c}\text { Total for } \\
\text { Department of } \\
\text { Defense }\end{array}$ & 42.20 & 49.06 & 17.47 & 0.06 & 3.50 & 1.34 & 2.39 & 5.01 \\
\hline $\begin{array}{r}\text { Total for } \\
\text { Department of } \\
\text { State }\end{array}$ & 6.64 & 20.48 & 20.63 & 24.09 & 20.59 & 37.98 & 7.80 & 30.34 \\
\hline $\begin{array}{c}\text { TOTAL US } \\
\text { Government } \\
\text { Assistance }\end{array}$ & 124.38 & 159.80 & 123.49 & 135.82 & 133.90 & 171.94 & 114.37 & 707.97 \\
\hline
\end{tabular}

Figures are compiled by the author from annual reports of the Department of State, Bureau of European and Eurasian Affairs. [Online]. Available at: http://www.state.gov/p/eur/rls/rpt/

* FSA funds are the foreign assistance delivered to the post-Soviet countries in accordance with the Freedom Support Act of 1992. These funds are typically used for the programs administered by USAID (e.g., economic restructuring, humanitarian assistance, democratic reform, private sector initiatives, and others), Department of State (law enforcement and counterterrorism programs, border security, and others); Department of Commerce, Department of Agriculture, Department of Homeland Security, and others.

** Non-FSA Funds include funding for certain USAID programs (e.g., international disaster assistance, health programs, and others), Department of State programs (foreign military financing, anti-terrorism assistance, non-proliferation and disarmament, export control and border assistance, etc.), Department of Defense programs, and initiatives of the Department of Energy, Department of Labor, and Department of Agriculture.

All this suggests that the United States has been a salient utilitarian reference group for Georgia, which rewards and punishments could have steered the course of the Georgian reform in one direction or another. Unfortunately, until recently the American administration has not used its leverage over Georgia for promoting human rights. The US legislation contains stipulations about the conditionality of American aid upon economic and political progress, adherence to human rights, and other circumstances. The definition of these circumstances, however, is left up to the presidential discretion. The conditions of foreign assistance defined by the Congress can also be waived (Tarnoff 2007). The Bush administration had not raised any concerns with increasingly loud threats to democracy and numerous undemocratic elements 
lurking in the shadow of the Georgian state-building. Instead, it provided the Saakashvili government with inflated assessment and misleading feedback on the state of human rights and democracy. In this way, it contributed to a distorted self-image of the country and unrealistic assessment of its progress in the areas of democracy building and human rights.

The Bush cabinet made no reservation in calling the republic a model of free market, a beacon of democracy, and a conduit of the US democratization goals in the post-Soviet territory, and the Georgian government basked in exuberant praises of the US administration for the conduct of its reforms (Congressional Presentation for Foreign Operations for FY2007 as cited in Nichol 2008a: 29). President Bush expressed unconditional political support to Georgia and avoided public criticisms of its administration. In rejoinder to critics of Georgia's human rights violations, the US gave the Georgian government the benefit of the doubt hailing its good intentions and promises of respect for human rights (HRW 2007: 99). Furthermore, an increasingly personal relationship between the Saakashvili and Bush administrations not only veiled the Georgian president from the American president's criticism, but also fostered the development of anti-American sentiments in the Georgian public, and disappointments in some of the Georgian partners in Europe, who raised questions about American genuine commitment to promoting democracy abroad.

Until recently, the US, itself, with its sullied human rights records had served as a poor model for human rights practices in Georgia. Some human rights organizations claim that the attitude of indifference toward human rights in the republic made the US administration indirectly responsible for instances of human rights violations in Georgia. According to some analysts, the US policies and statements toward Georgia may have led President Saakashvili to miscalculate the extent of American security support when he ordered the Georgian troops to South Ossetia.

Obama's team seems to have learned from the faux pas of the Bush administration. Devoid of any personal undertones, the Obama administration's approach to Georgia is suggestive of the greater concern with the country's progress toward democracy, rather than support of a friendly regime. There are some elements of continuity in the US policy toward Georgia and the strategy embraced by the previous administration, but the rhetoric has largely changed from the one that failed to recognize the fragile and fledgling character of Georgia's democracy to public acknowledgements that the country has more work to do to become a democratic state. Whether the democracy promotion programs of the Obama administration will match the reality and needs of the country to build and consolidate advancements in the areas of democracy and human rights is yet to be seen.

The EU has been a locomotive for establishing, promoting, and defending the best human rights practices in Europe. Yet, it has not become an external anchor for the reform process in Georgia. Although, the EU has spent hundreds of millions of US dollars on Georgia to fund a wide range of projects, its approach has been "scattergun and piecemeal, not strategic" (Leonard and Grant 2005: 6). In 2006, Georgia and the EU signed a European Neighborhood Policy Action Plan that laid out new benchmarks for Georgia's democratization reforms and provided for additional financial assistance for a host of projects. Still, focus on stand-alone projects, inadequate delivery mechanisms, and the lack of engagement have detracted from the effectiveness of the European initiatives in Georgia (European Commission 2007). Since the European Union has not provided Georgia with the much needed security guarantees or assisted politically to the extent desired by the Georgian government, the EU had only limited influence over the government of Georgia. The Saakashvili administration is fully aware that Georgia's 
membership in the EU is out of question at present time. It, therefore, has adopted a pragmatic approach toward the Union's program. It has taken advantage of the European financial and expert assistance, and concentrated on promoting bilateral trade and economic relations with the EU. Yet, its democratic reforms have not fully followed the requirements of the Union, particularly, as far as the rule of law and prerogatives of human rights are concerned.

\section{Discussion and Conclusions}

This study was motivated by a puzzling inconsistency between the Saakashvili government's avowed commitments to human rights and democracy in Georgia and departures from these pledges in practice. I attributed the persistent breaches of civil, political, and personal integrity rights in Georgia not only to its domestic circumstances, but also to the international impact. In this research, I developed and applied a theory of reference groups to demonstrate how social groups of states influence policies and behavior of their members. The analysis presented in this study demonstrated how Georgia's reference groups, particularly, the US, contributed to its retreat in the area of human rights in the post-Rose Revolution era by (1) supporting the Georgian government in its goal of rebuilding the state prior to democratizing it and strengthening respect for human rights; (2) re-directing foreign assistance from democratization and human rights initiatives to state-building projects, and (3) providing the Georgian government with a flattering, yet, misleading feedback concerning the republic's accomplishments in the area of human rights.

The reference group perspective does not contradict to the existing accounts of human rights violations, most of which rely on either rationalist logic explaining state behavior in functional terms (the actor performs an action if the costs associated with it do not exceed the expected benefits from the action) or constructivist logic stressing the importance of social context and impact of ideational forces, such as identity, culture, and norms. Contrary to the rationalist explanations assuming that states act as rational utility-maximizing agents, I treat states as social actors and draw attention to the impact of social environment in which states operate. In this, my research comes close to constructivism. In contrast to constructivist and other international-level accounts, which rarely provide systematic accounts for why some states or groups of states are more influential in politics of other nations, reference group theory systematizes mechanisms and scope conditions under which different types of social influence occur. The reference group perspective provides an integrative framework of normative and strategic sources of international influence on the assumption that by studying the interplay of strategic behavior with social forces our understanding of how states transform their views and policies can be considerably improved.

A key theme that emerged from this research is that Western democracies may fall through in their efforts at democratization and human rights promotion even when those efforts are well received by states seeking identification and social integration with the West and willing to undergo changes in the expected direction. The good intentions of democracy promotion do not always translate into appropriate policies, even when conditions for erecting democratic institutions are ripe in the target state. This happened in the republic of Georgia, where the United States, for example, sided with the Georgian government when it showed the first signs of understating the importance of continuous democratization and respect for human rights. Although, the post-Rose Revolution accomplishments in Georgia were remarkable, many of the state-building goals were realized at a very high price of judicial independence, strong executive branch, media freedoms, political pluralism, and human rights. In a long run, the approach adopted by the Saakashvili administration and endorsed by the Western states fired back. 
Empowered state began encroaching on civil, political, and personal integrity rights. Georgia's stalled democratization stirred up domestic political strife, which, in turn, slowed down the statebuilding momentum (Mitchell 2009a: 178-9). Not only was the Bush administration reluctant to use its leverage in Georgia in order to disrupt the movement away from consolidation and strengthening of the initial democratic gains, but also reduced its support to civil society and mass media and re-routed its financial flows to facilitate Saakashvili's state-building projects. Finally, the United States has contributed to the cultivation and dissemination of a distorted narrative about Georgia as a thriving democracy. This misleading portrayal has been harmful not only to Georgia, but also to Washington itself, which has been blamed for stretching its definition of democracy to accommodate a new ally (Mitchell 2009b).

Given the strong influence that the US has over the Georgian government, the Obama administration should use this opportunity for influencing human rights records in the republic. Particularly now when the power of the Georgian government is still tenuous, and the country's political situation is unstable in the aftermath of the months of protests and the attempted coup by the Georgian military in 2009. The American aid to Georgia should be conditional on the Georgian administration's unwavering commitment to human rights and democratization. Without the US support, the future of democracy in Georgia is uncertain. There is a danger of further democratic backsliding and reversal of accomplishments on the political and socioeconomic fronts. Today, the official position of the US toward Georgia is continuing assistance to the republic on all dimensions of cooperation. The US endorses Georgia's sovereignty and territorial integrity, and does not recognize independence of the breakaway territories. This position is shared by other European states and international organizations. American attitude toward Georgia is unlikely to change as many in the Obama administration, including the Vice President, Joe Biden, and the Secretary of State, Hillary Clinton, view Georgia as an important strategic partner for the US in the South Caucuses and harbor warm feelings toward the American protégé.

Translating verbal support into concrete actions will be more problematic. Facing staunch opposition to Georgia's membership in NATO from France and Germany and lack of support from all but newly admitted members of the Alliance, and disillusioned with the weaknesses of the Georgian armed force detailed in a Pentagon report, the US may put brakes on acceleration of Georgia's membership in NATO (Kucera 2009). Should this be the case, then the US administration must be unambiguous in its support of Georgia's aspiration of integration in NATO. The NATO membership remains a plausible aim, but it is not a realistic goal in a shortterm or even medium-term perspective. Many signals coming from the White House suggest that the Obama administration is interested in improving relations with Russia and enlisting its support in dealing with Iran's nuclear program, stabilization of Afghanistan, and strengthening the international non-proliferation framework. The nature of the US-Russian relationship will directly affect Georgia. If Washington is sincere in its pledge to press a "reset" button in relations with Moscow, it will face a big challenge of rebuilding its ties with the Kremlin without abandoning Georgia or compromising the republic's interests. Georgia, too, in order to sustain the high level of support from the Obama administration, needs to rethink the rationale for assistance from the US. American officials have already demonstrated some signs of annoyance at Georgia's overheated rhetoric accusing the Kremlin for every flaw in its reforms and playing the Russian card to discredit the Georgian opposition.

The US should enlist support of the European Union and other European institutions for democracy promotion in the republic. In the past, the greatest advances in the area of 
democratization and human rights in Georgia were made when Europe and the US worked in tandem. It is an opportune moment for the EU to step up its role in the country. After a period of a near standstill in relations with the republic at the beginning of 2009, the new Eastern Partnership program is a welcomed initiative. However, the nature of this program is not to resolve the kinds of crises plaguing Georgia. The EU needs to act quickly and attend to the shortterm problems in Georgia by providing the republic with more political and financial support (Wilson and Popescu 2009). The EU should continue promoting democratic governance in Georgia, and make it very clear to the Georgian cabinet that future assistance to the republic hinges upon its commitment to the rule of law, democratic principles, and human freedoms. Notes

${ }^{1}$ For an excellent review of the existing explanations of human rights practices worldwide, see Schmitz and Sikkink 2002.

${ }^{2}$ Originally conceived by social psychologists, reference group theory has been applied across a range of disciplines in such areas as formal organization, marketing, consumer behavior, and juvenile delinquency, among others. In political science, the concept of reference group appeared in the studies of political opinion and behavior. Recently, it surfaced in the analyses of behavior of states and political elites.

${ }^{3}$ It is not to say that other states or international organization played no role in the politics of Georgia. In relative terms, however, their impact has been moderate compared to kind of authority projected on Georgia by the US, Russia, and the EU. 


\section{References}

AMNESTY INTERNATIONAL. (2007) Georgia: Briefing to the United Nations Human Rights Committee. EUR 56/008/2007. 30 October. [Online]. Available:

http://www.amnesty.org/en/library/ info/EUR56/008/2007 [3 December 2009].

AMNESTY INTERNATIONAL. (2009) Georgia: Police Reportedly Use Excessive Force against the Demonstrators. EUR 56/001/2009. 23 June. [Online]. Available:

http://www.amnesty.org/en/library/info/EUR56/001/2009/en [10 January 2010].

AGYEMAN-DUAH, Baffour, and OLATUNDE, Ojo B.J. (1991) Interstate Conflicts in West Africa: The Reference Group Theory Perspective. Comparative Political Studies, 24, pp. 299318.

BLANTON, Hart, and CHRISTIE, Charlene. (2003) Deviance Regulation: A Theory of Action and Identity. Review of General Psychology, 7, pp. 115-149.

COMMITTEE AGAINST TORTURE. (2006) Considerations of Reports Submitted by States Parties under Article 19 of the Convention against Torture and Other Cruel, Inhuman or Degrading Treatment or Punishment: Conclusions and Recommendations of the CAT/C/GEO/CO/3, United Nations, 25 July.

CURLEY, Tyler M. (2009) Social Identity Theory and EU Expansion. International Studies Quarterly, 53, pp. 649-68.

CURTIS, Glenn E., ed. (1995) Armenia, Azerbaijan, and Georgia: Country Studies (Washington, D.C.: Federal Research Division, Library of Congress).

EUROPEAN COMMISSION. (2007) European Neighborhood and Partnership Instrument:

Georgia. Country Strategy Paper 2007-2013. [Online]. Available:

http://ec.europa.eu/world/enp/pdf/country/enpi_csp_georgia_en.pdf [1 June 2009].

GEORGE, Julie A. (2009) The Dangers of Reform: State Building and National Minorities in Georgia. Central Asian Survey, 28, pp. 135-154.

GOVERNMENT OF GEORGIA. (2005) Georgia Since the Rose Revolution. [Online].

Available: www.president.gov.ge/others/Report.pdf [14 June 2009].

HEREK, Gregory M. (1986) The Instrumentality of Attitudes: Toward a Neofunctional Theory. Journal of Social Issues, 42, pp. 99-114.

HUMAN RIGHTS INFORMATION AND DOCUMENTATION CENTER (HRIDC). (2004).

One Step Forward, Two Steps Back: Human Rights in Georgia after the "Rose Revolution. [Online]. Available: http://66.116.100.86/humanrights.ge/eng/files/ REPORT.pdf [13 February 2009].

HRIDC. (2006a) Human Rights Violations in Georgia: Alternative Report to the United Nations Committee against Torture. [Online]. Available: http://www.humanrights.ge/eng/

files/Georgia_report_v71.pdf [13 February 2009].

HRIDC. (2006b) Next Stop - Belarus? Human Rights in Georgia 2005. [Online]. Available: http://www.humanrights.ge/files/HR-REPORT-2006.pdf [13 February 2009].

HRIDC. (2008) Georgia's Parliamentary Elections - Unprecedented Brutality and Election

Fraud: Monitoring of Elections of May 21, 2008. [Online]. Available:

http://www.nhc.no/php/files/documents/land/Georgia/Election_report_Georgia.pdf.

HUMAN RIGHTS WATCH (HRW). (2006) Undue Punishment: Abuses against Prisoners in Georgia. Vol. 18, No.8(D). [Online]. Available: http://www.hrw.org/sites/default/files/reports/ georgia0906webwcover.pdf [15 March 2009]. 
HRW. (2007) Crossing the Line: Georgia's Violent Dispersal of Protesters and Raid on Imedi Television. Vol. 19, No. 8(D), December. [Online]. Available: www.hrw.org/ en/reports/2007/12/19/crossing-line [13 March 2009]. HRW. (2009a). Justice is Not Negotiable. [Online]. Available: http://www.hrw.org/en/ news/2009/05/11/georgia-justice-not-negotiable [13 June 2009].

HRW. (2009b) Up in Flames: Humanitarian Law Violations and Civilian Victims in the Conflict over South Ossetia. [Online]. Available: http://www.hrw.org/sites/default/ files/reports/georgia0109web.pdf [13 June 2009].

HRW. (2009c) World Report 2009: Georgia. [Online]. Available: http://www.hrw.org/en/ ode/79339 [13 June 2009].

HYMAN, Herbert H. (1968) 'Reference Groups', in International Encyclopedia of the Social Sciences. Vol. 13, (ed.) D. Sills (New York: Macmillan Company \& Free Press), pp. 353-359. INTERNATIONAL CRICIS GROUP (ICG). (2007) Georgia: Sliding Towards Authoritarianism? Europe Report No.189, 19 December. [Online]. Available: http://www.crisisgroup.org/library/documents/189 georgia sliding towards authoritarianism. pdf [1 June 2009].

INTERNATIONAL FEDERAITON FOR HUMAN RIGHTS (IFHR). (2006) Situation of Human Rights in Georgia. FIDH Note. 14 November. [Online]. Available:

http://www.hra.am/file/fidhnotegeorgia.pdf [13 March 2009]. KELLEY, Harold H. (1952) 'Two Functions of Reference Groups.' In Society for the Psychological Study of Social Issues, Readings in Social Psychology, (ed.) G. Swanson, T. Newcomb, and E. Hartley (New York: Holt), pp. 410-414.

KUCERA, Joshua. (2009) Georgia: Tbilisi Tries to Get a Feel for the Obama Administration. Eurasia Insight. 6 March. [Online]. Available: http://www.eurasianet.org/ departments/insightb/articles/eav030609a.shtml [13 June 2009].

KUKHIANIDZE, Alexandre. (2009) Corruption and Organized Crime in Georgia Before and After the "Rose Revolution." Central Asian Survey, 28, pp. 215-234.

LEONARD, Mark, and GRANT, Charles. (2006) Georgia and the EU: Can Europe's Neighborhood Policy Deliver? Center for European Reform. 6 April. [Online]. Available: www.cer.org.uk/pdf/policybrief belarus 6april06.pdf [13 March 2008].

LOBJAKAS, Ahto. (2006) Georgia: Solana Fears Kosovo 'Precedent' for Abkhazia, South Ossetia. RFE/RL. 6 October. [Online]. Available:

http://www.rferl.org/featuresarticle/2006/10/8748c1ca-a82c-444b-b2a9-df357251aa54.html [11 March 2007].

MILLENIUM CHALLENGE CORPORATION. (2005) Georgia and Millennium Challenge Corporation: Building a Partnership for Poverty Reduction through Sustainable Economic Growth. 12 September. [Online]. Available: http://www.mca.gov/press/factsheets/2005/ factsheet-091205-georgia.php

MITCHELL, Lincoln A. (2009a) Compromising Democracy: State Building in Saakashvili's Georgia. Central Asian Survey, 28, pp. 171-183.

MITCHELL, Lincoln A. (2009b) Georgia's Story: Competing Narratives since the War. Survival, 51, pp. 87-100.

MITCHELL, Lincoln A. (2009c) Uncertain Democracy: U.S. Foreign Policy and Georgia's Rose Revolution (Philadelphia: University of Pennsylvania Press).

MOONEY, Christopher Z. (2001) Modeling Regional Effects on State Policy Diffusion. Political Research Quarterly, 54, pp. 102-24. 
NICHOL, Jim. (2005) Georgia [Republic]: Recent Developments and U.S. Interests. CRS Report for Congress, 11 March. [Online]. Available:

https://www.policyarchive.org/bitstream/handle/10207/443/97-727 20050311.pdf?sequence=1 [11 March 2009].

NICHOL, Jim. (2008a) Armenia, Azerbaijan, and Georgia: Security Issues and Implications for U.S. Interests. CRS Report for Congress, 31 January. [Online]. Available:

http://www.fas.org/sgp/crs/row/RL30679.pdf [11 March 2009].

NICHOL, Jim. (2008b) Georgia [Republic] and NATO Enlargement: Issues and Implications", CRS Report for Congress, 7 March [Online]. Available:

http://www.usembassy.at/en/download/pdf/nato georgia.pdf [11 March 2009].

PAPAVA, Vladimer. (2006) The Political Economy of Georgia's Rose Revolution. Orbis, 50, pp. 657-667.

PARLIAMENT OF GEORGIA. (2005) Resolution Regarding the Current Situation in the Former Autonomous District of South Ossetia and Ongoing Peace Process, November 11. [Online]. Available: http://www.parliament.ge/index.php?lang id $=$ ENG\&sec_id=98\&info_id=7267 [11 March 2009].

PARLIAMENT OF GEORGIA. (2006) Appeal of the Parliament of Georgia to the Parliaments of NATO Member-States. 5 May. [Online]. Available:

http://www.parliament.ge/print.php?gg=1\&sec id =98\&info_id=11644\&lang_id=ENG.

ROSE, Richard. (1993) Lesson-Drawing in Public Policy: A Guide to Learning across Time and Space (Chatham: Chatham House).

SAAKASHVILI, Mikhail. (2004a) Speech of the President of Georgia at the Parliamentary Assembly Meeting, Strasburg, January 28. [Online]. Available: http://www.saakashvili.com/ page 4.html [9 May 2008].

SAAKASHVILI, Mikhail. (2004b) My vypolnili to, shto obeschali [We accomplished what we promised]. The New Europe Review. 19 December. [Online]. Available:

http://www.president.gov.ge/ print txt.php?id=370\&l=E.

SAAKASHVILI, Mikhail. 2005. Annual report of the President of Georgia to Parliament.

February 10. [Online]. Available:

http://www.president.gov.ge/?1=E\&m=0\&sm=6\&st=0\&id=1491 [10 January 2010].

SAAKASHVILI, Mikhail. 2006. Annual address of the President of Georgia to Parliament.

February 14. [Online]. Available: http://www.president.gov.ge/print txt.php?id=1451\&l=E [9 May 2008].

SCHMITZ, Hans P., and SIKKINK, Kathryn. (2002) International Human Rights. In Handbook of International Relations. (eds.) W. Carlsnaes, T. Risse, and B.A. Simmons (Thousand Oaks, CA: Sage), pp. 517-538.

SHANKER, Thom, and CHIVERS, C.J. (2008) Georgia Lags in Its Bid to Fix Army. The New York Times, 17 December. [Online]. Available: http://www.nytimes.com/2008/

12/18/world/europe/18georgia.html [1 June 2009].

SUMBADZE, Nana. (2009) Saakashvili in Public Eye: What Public Opinion Polls Tell Us.

Central Asian Survey, 28, pp. 185-197.

TAMRAZIAN, Harry, and ALIYEV, Kenan. (2006). EU: Solana Says Membership for Caucasus "A Different Story." RFE/RL. 15 November. [Online]. Available: http://www.rferl.org/featuresarticle/2006/11/49cc53a7-9595-4960-ba54-0ba1f248963f.html [9

May 2008]. 
TARNOFF, Curt. (2007) U.S. Assistance to the Former Soviet Union. CRS Report for Congress, 1 March. [Online]. Available: http://www.fas.org/sgp/crs/row/RL32866.pdf.

TATUM, Jesse D. (2009) Democratic Transition in Georgia: Post-Rose Revolution Internal Pressures on Leadership. Caucasian Review of International Affairs, 3, pp. 156-171.

TUDOROIU, Theodor. (2007) Rose, Orange, and Tulip: The Failed Post-Soviet Revolutions. Communist and Post-Communist Studies, 40, pp. 315-342.

USAID. (2006) Data Sheet: USAID Mission in Georgia. [Online]. Available: http://www.usaid.gov/policy/budget/cbj2006/ee/pdf/ge 114-0231.pdf [10 January 2010]. USAID. (2009) Europe and Eurasia Regional Program Overview. [Online]. Available: www.usaid.gov/policy/budget/cbj2009/101440.pdf [10 January 2010]. U.S. DEPARTMENT OF STATE. BUREAU OF DEMOCRACY, HUMAN RIGHTS, AND LABOR. (2008) Country Reports on Human Rights Practices: Europe and Asia: Georgia, 2007. [Online]. Available: http://www.state.gov/g/drl/rls/hrrpt/ 2007/100560.htm [20 March 2009]. U.S. DEPARTMENT OF STATE. BUREAU OF DEMOCRACY, HUMAN RIGHTS, AND LABOR. (2007) Country Reports on Human Rights Practices: Europe and Asia: Georgia, 2006. [Online]. Available: http://www.state.gov/g/drl/rls/hrrpt/2006/78813.htm.

U.S. Embassy in Georgia. (2009) Remarks to the Media by ASD Vershbow and Deputy FM Bokeria after the Meeting of the Security Working Group. Tbilisi. 20 October. [Online]. Available: http://georgia.usembassy.gov/transcripts/remarks-to-the-media-by-asd-vershbow-anddeputy-fm-bokeria-after-the-meeting-of-the-security-working-group-to-the-media-october20.html [10 January 2010]. VASILJEVA, Olga. (1997) Rossiiski factor vo vneshnei politike Gruzii (1990-95) [Russian factor in Georgia's foreign policy (1990-95)] (Moscow: IGRUNOV). [Online]. Available: http://www.igpi.ru/info/people/vasiljeva/autoref.html [20 March 2008]. WEIL, Frederick. (1993) The Development of Democratic Attitudes in Eastern and Western Germany in a Comparative Perspective. In Research on Democracy and Society:

Democratization in Eastern and Western Europe. Vol.1. (ed.) F. Weil (Greenwich: JAI Press), pp. 195-225.

THE WHITE HOUSE. (2009) Remarks by the Vice President to the Georgian Parliament. Tbilisi. 23 July. [Online]. Available: http://www.whitehouse.gov/the press office/Remarks-ByThe-Vice-President-To-The-Georgian-Parliament/ [10 January 2010]. 